Tanjungpura Law Journal, Vol. 4, Issue 2, July 2020: 178 - 190

ISSN Print: 2541-0482 | ISSN Online: 2541-0490

Open Access at: http://jurnal.untan.ac.id/index.php/tlj

Article Info

Submitted: 21 Mei 2020 | Reviewed: 20 Juni 2020 | Accepted: 12 Juli 2020

\title{
LARANGAN TINDAKAN PERSEKONGKOLAN DALAM TENDER BERDASARKAN UNDANG-UNDANG NOMOR 5 TAHUN 1999 TENTANG LARANGAN PRAKTIK MONOPOLI DAN PERSAINGAN USAHA TIDAK SEHAT
}

\author{
Resmaya Agnesia Mutiara Sirait ${ }^{1}$
}

\begin{abstract}
One of the substance of Law Number 5 Year 1999 concerning Prohibition of Monopolistic Practices and Unfair Business Competition is the provision that regulates collusion in tenders. The provision is regulated in Article 22 which is a special provision with the aim of creating a conducive business climate to support and develop activities for the provision of quality goods and services and at competitive prices. Considering that the impact of the conspiracy in tenders is very significant for national economic development and a healthy competitive climate, the regulation regarding the prohibition of tender conspiracy can be applied both with a rule of reason approach and with a per se illegal approach, so that administrative sanctions and criminal sanctions as well as additional criminal sanctions that will be imposed on business actors can run as desired by Law Number 5 Year 1999. The impact of collusion actions in tenders is not just economic development National and unfair competition climate, but other impacts can be felt by consumers as tender givers who can experience material and immaterial losses. Consumer protection is needed as an effort made to safeguard consumer rights and develop behavior attitudes of responsible business actors.
\end{abstract}

Keywords: conspiracy in tender; monopoly; unfair competition

\begin{abstract}
Abstrak
Salah satu substansi Undang - Undang Nomor 5 Tahun 1999 Tentang Larangan Praktik Monopoli Dan Persaingan Usaha Tidak Sehat adalah ketentuan yang mengatur persekongkolan dalam tender. Ketentuan tersebut diatur dalam Pasal 22 yang merupakan ketentuan khusus dengan tujuannya untuk menciptakan iklim usaha yang kondusif guna mendukung dan menumbuh kembangkan kegiatan penyediaan barang dan jasa yang berkualitas dan dengan harga yang bersaing. Mengingat dampak yang ditimbulkan dari tindakan persekongkolan dalam tender sangat signifikan bagi pembangunan ekonomi nasional dan iklim persaingan yang sehat, maka pengaturan mengenai larangan persekongkolan tender dapat diterapkan baik dengan pendekatan secara rule of reason maupun dengan pendekatan secara per se illegal, sehingga sanksi administratif dan sanksi pidana serta pidana tambahan yang akan dijatuhkan pada pelaku usaha dapat berjalan sebagaimana yang dikehendaki oleh Undang - Undang Nomor 5 Tahun 1999. Dampak yang ditimbulkan dari tindakan persekongkolan dalam tender bukan hanya kepada pembangunan ekonomi nasonal dan iklim persaingan tidak sehat, akan tetapi dampak lain dapat dirasakan oleh konsumen selaku pemberi tender yang dapat mengalami kerugian materiil maupun immaterial. Perlindungan konsumen diperlukan sebagai suatu upaya yang dilakukan untuk menjaga hak-hak konsumen dan menumbuh kembangkan sikap perilaku pelaku usaha yang bertanggung jawab.
\end{abstract}

Kata Kunci: monopoli; persaingan usaha tidak sehat; persekongkolan dalam tender

\footnotetext{
${ }^{1}$ Fakultas Hukum Universitas Padjajaran Bandung, Jalan Badan Nomor 42, Bandung, Kode Pos: 40265, Email: agnesiamutiara@gmail.com, Telp: 082251353536
} 


\section{Pendahuluan}

Meningkatkan kehidupan masyarakat yang adil dan makmur serta sejahtera merupakan cita-cita Negara Indonesia yang diamanatkan dalam UUD 1945 dan Pancasila. Salah satu kegiatan yang diperlukan untuk mewujudkan cita-cita bangsa Indonesia adalah dengan melakukan pembangunan perekonomian. Pembangunan perekonomian Indonesia selalu berkaitan dengan tindakan praktek monopoli dan persaingan usaha yang tidak sehat.

Untuk menghindari kegiatan monopoli dan persaingan usaha tidak sehat dalam pembangunan perekonomian di Indonesia, telah dikelurkan oleh pemeirntah peraturan Undang-Undang Nomor 5 Tahun 1999 tentang Larangan Praktek Monopoli dan Persaingan Usaha Tidak Sehat (selanjutnya disebut UU Nomor 5 Tahun 1999). Dalam UU Nomor 5 Tahun 1999 ditetapkan adanya asas demokrasi di dalam perekonomian Indonesia, dimana semua pelaku usaha pada saat menjalankan kegiatan usaha harus dapat membedakan secara seimbang antara kepentingan dari pelaku usaha dengan kepentingan umum.

Tujuan dari UU Nomor 5 Tahun 1999 adalah untuk menjaga persaingan antara pelaku usaha menjadi sehat. Selain itu, juga menjadi payung hukum untuk mengantisipasi dan mengatasi permasalahan-permasalahan yang timbul dari kompetisi antar pelaku usaha dalam merebut pasar dunia usaha.
Guna mendukung kondisi persaingan usaha yang sehat, terbuka dan dicitacitakan oleh banyak pelaku usaha, maka diperlukan kebijakan persaingan usaha. Penting dan perlunya kebijakan persaingan usaha dimiliki oleh suatu negara bertujuan untuk meminimalkan inefisiensi perekonomian yang diakibatkan oleh perilaku pelaku usaha yang cenderung bersifat anti persaingan dan berkeinginan melakukan praktek monopoli seenaknya. ${ }^{2}$

UU Nomor 5 Tahun 1999 membagi dalam 2 (dua) pengaturan substansi yaitu perjanjian yang dilarang dan kegiatan yang dilarang. Kegiatan yang termasuk dalam kegiatan yang dilarang adalah kegiatan monopoli, monopsoni, penguasan pasar serta persekongkolan (collusive tendering). Perbedaan antara kegiatan dilarang dan perjanjian yang dilarang umumnya dilihat dari jumlah pelaku usahanya. ${ }^{3}$

Salah satu masalah mendasar persaingan usaha di Indonesia adalah berkenaan dengan proses pengadaan barang dan jasa pemerintah. Dalam proses pengadaan barang dan jasa pemerintah, dinilai oleh beberapa kalangan banyak dijumpai praktik persekongkolan untuk menentukan pemenang dalam sebuah tender. ${ }^{4} \mathrm{Hal}$ ini bertentangan dengan prinsip-prinsip serta mekanisme yang

\footnotetext{
${ }^{2}$ Faisal Basri. 2002. Perekonomian Indonesia, Tantangan dan Harapan Bagi Kebangkitan Indonesia. Jakarta: Erlangga, hlm. 326.

${ }^{3}$ Rachmadi Usman. 2013. Hukum Persaingan Usaha Di Indonesia, Jakarta: Sinar Grafika, hlm 369.

${ }^{4}$ Yakub Adi Krisanto. 2008. "Terobosan Hukum Keputusan KPPU dalam Mengembangkan Penafsiran Hukum Persekongkolan Tender". Jurnal Hukum Bisnis, 27 (3), hlm. 63.
} 
sudah diatur dalam Perpres Nomor 54 Tahun 2010 Tentang Pengadaan Barang / Jasa Pemerintah serta UU Nomor 5 Tahun 1999.

Dalam tender tidak menutup kemungkinan adanya kecurangan atau pelanggaran dalam proses tender itu sendiri. Salah satunya adalah persekongkolan di antara peserta tender dan/atau dengan penyelenggara tender. Suatu persekongkolan dalam tender dapat dilakukan secara terang-terangan maupun diam-diam melalui tindakan penyesuaian, penawaran sebelum dimasukkan, atau menciptakan persaingan semu, atau menyetujui dan atau memfasilitasi, atau pemberian kesempatan eksklusif, atau tidak menolak melakukan suatu tindakan meskipun mengetahui bahwa tindakan tersebut dilakukan untuk mengatur dalam rangka memenangkan peserta tender tertentu. Di Indonesia, masalah ersekongkolan tender diatur dalam UU Nomor 5 Tahun 1999, pada Pasal 22 tidak hanya mencakup kegiatan pengadaan yang dilakukan pemerintah, tetapi juga kegiatan pengadaan yang dilakukan oleh perusahaan negara (BUMN/BUMD) dan perusahaan swasta. $^{5}$

Pada hakikatnya persekongkolan tender merupakan suatu perbuatan yang dilakukan, baik oleh pihak penyedia barang

5 Octaviana Pramustika Puteri, Teddy Anggoro. 2013. "Dugaan Praktel Persaingan Usaha Tidak Sehat Dalam Proyek Pembangunan Pegangasaan Timur Cikini Ditinjau Dari Undang-Undang Nomor 5 Tahun 1999 Tentang Larangan Praktek Monopoli dan Persaingan Usaha Tidak Sehat". Jurnal Hukum. dan jasa maupun pengguna barang/jasa untuk mengatur dan menentukan pemenang tender. ${ }^{6}$ Dalam Undang Undang Larangan Praktik Monopoli dan Persaingan Usaha Tidak Sehat, persekongkolan diatur di dalam Pasal 22 sampai Pasal 24. Persekongkolan tender diatur secara khusus dalam Pasal 22 Undang - Undang Monopoli dan Persaingan Usaha Tidak Sehat yang menyatakan bahwa, pelaku usaha dilarang bersekongkol dengan pihak lain untuk mengatur dan atau menentukan pemenang tender sehingga dapat mengakibatkan terjadinya persaingan usaha tidak sehat. ${ }^{7}$

Akhir - akhir ini, masalah berkaitan dengan persekongkolan tender pengadaan barang dan jasa. Pengadaan barang dan jasa yang dilakukan oleh pelaku usaha seperti pemerintah, perusahaan negara atau perusahaan swasta sering dikaitkan dengan persekongkolan dalam pemenangan tender. Dalam proses pengadaan barang dan jasa oleh pemerintah, sering ditemukan praktik persekongkolan untuk menentukan pemenang dalam sebuah tender.

Berdasarkan pemaparan di atas maka diperlukan pengkajian terhadap permasalahan pengadaan barang dan jasa. Hal ini disebabkan adanya permasalahan tindakan persekongkolan

6 Yakub Adi Kristanto, Op Cit, hlm 72.

7 Riski Dysas Prabawani, Munawar Kholil. 2017. "Analisis Yuridis Penegakan Hukum Persekongkolan Tender Menurut Undang-Undang Nomor 5 Tahun 1999 Tentang Larangan Praktik Monopoli Dan Persaingan Usaha Tidak Sehat". Jurnal Hukum, Privat Law, V (2), hlm. 78 
dalam tender yang terjadi pada proses pengadaan barang dan jasa yang menyimpang terhadap UU Nomor 5 Tahun 1999 sebagai payung hukum dalam tindakan praktik monopoli dan persaingan usaha tidak sehat. Fakta yang terjadi dalam masyarakat

mengenai penyimpangan terhadap ketentuanketentuan di dalam UU Nomor 5 Tahun 1999 yang sering kali terjadi dan perlu adanya kajian mengenai masalah tersebut. Maka dari itu berdasarkan hal-hal yang telah diuraikan, tulisan ini akan mengkaji mengenai penegakan hukum terhadap adanya tindakan persekongkolan dalam tender dikaitkan dengan UU Nomor 5 Tahun 1999 dan dampak yang akan dialami konsumen apabila terjadi tindakan persekongkolan dalam tender dikaitan dengan perlindungan konsumen.

\section{Metode}

Penelitian ini bertujuan mengkaji larangan tindakan persekongkolan dalam tender berdasarkan dengan UU Nomor 5 Tahun 1999. Penelitian ini merupakan jenis penelitian hukum normatif bersifat preskriptif dengan menggunakan pendekatan perundang-undangan (statute approach). Menggunakan sumber bahan hukum primer, sekunder, dan tersier yang di kumpulkan dari studi dokumen atau studi kepustakaan (library research) dengan analisis bahan hukum yang bersifat deduksi dengan metode silogisme yang berpangkal dari premis mayor (pernyataan bersifat umum). Kemudian diajukan premis minor (bersifat khusus) dan dari kedua premis itu kemudian ditarik suatu kesimpulan atau conclusion.

III. Analisis dan Pembahasan

A. Tindakan Persekongkolan Dalam Tender Dikaitkan Dengan UndangUndang Nomor 5 Tahun 1999 Tentang Larangan Praktik Monopoli Dan Persaingan Usaha Tidak Sehat.

Persaingan usaha yang dilakukan secara tidak jujur dapat dilihat dari cara pelaku usaha dalam bersaing dengan pelaku usaha lain. Misalnya, dalam persaingan tender, para pelaku usaha telah melakukan konspirasi usaha dengan panitia lelang untuk dapat memenangkan sebuah tender. Sehingga pelaku usaha lainnya tidak mendapatkan kesempatan untuk memenangkan tender tersebut. ${ }^{8}$

Persaingan usaha yang dilakukan dengan cara melawan hukum dilihat dari cara pelaku usaha dalam bersaing dengan pelaku usaha lainnya dengan melanggar ketentuan-ketentuan perundang-undangan yang berlaku. Contohnya adanya pelaku usaha yang bebas pajak atau bea cukai. Kemudian adanya persaingan dengan cara menghambat terjadinya persaingan di antara pelaku usaha melihat kondisi pasar yang tidak sehat. Dalam pasar mungkin tidak terdapat kerugian pada pesaing lain, dan para pelaku usaha juga tidak mengalami kesulitan. Tetapi, perjanjian

\footnotetext{
8 Muskibah. 2013. "Larangan Persekongkolan Dalam Tender Perspektif Undang-Undang Nomor 5 Tahun 1999 Tentang Larangan Praktek Monopoli Dan Persaingan Usaha Tidak Sehat", Jurnal Hukum, 6 (7), hlm. 61
} 
yang dilakukan pelaku usaha menjadikan pasar bersaing secara tidak kompetitif. ${ }^{9}$

Persekongkolan merupakan karakteristik tersendiri, karena dalam persekongkolan (conspiracy / konspirasi) terdapat kerja sama yang melibatkan dua atau lebih pelaku usaha yang secara bersama-sama melakukan tindakan melawan hukum. Istilah persekongkolan pertama kali ditemukan pada Antitrust Law di USA yang didapat melalui Yurisprudensi Mahkamah Tertinggi Amerika Serikat, berkaitan dengan ketentuan Pasal 1 The Sherman Act 1890, dimana dalam pasal tersebut dinyatakan: "....persekongkolan untuk menghambat perdagangan ..... (.... Conspiracy in restraint of trade .....).

Mahkamah Tertinggi USA juga menciptakan istilah "concerted action", untuk mendefinisikan istilah persekongkolan dalam hal menghambat perdagangan, serta kegiatan saling menyesuaikan berlandaskan berdasarkan persekongkolan guna menghambat perdagangan serta pembuktiannya dapat disimpulkan dari kondisi yang ada. Berdasarkan pengertian di USA itulah, maka persekongkolan merupakan suatu perjanjian yang konsekuensinya adalah perilaku yang saling menyesuaikan (conspiracy is an agreement which has consequence of concreted action)..$^{10}$ Bentuk kegiatan persekongkolan ini tidak harus dibuktikan dengan adanya

\footnotetext{
9 Ibid.

${ }_{10}$ L. Budi Kagramanto. 2008. Larangan Persekongkoan Tender (Perspektif Hukum Persaingan Usaha). Surabaya: Srikandi, hIm 192.
}

perjanjian, akan tetapi bisa dalam kegiatan lainnya yang tidak mungkin diwujudkan dalam suatu perjanjian. ${ }^{11}$

Persekongkolan adalah kegiatan yang dilarang dan dapat berupa: ${ }^{12}$

1. Mengatur dan atau menentukan pemenang tender;

2. Bersekongkol untuk mendapatkan informasi kegiatan usaha persaingan yang diklasifikasikan sebagai rahasia perusahaan;

3. Bersekongkol untuk mendapatkan informasi diklasifikasikan sebagai rahasia perusahaan;

4. Menghambat produksi atau pemasaran barang dan atau jasa pelaku usaha pesaing dengan maksud agar barang dan atau jas yang ditawarkan atau dipasok di pasar bersangkutan menjadi kurang baik dari jumlah kualitas, maupun ketetapan yang disyaratkan.

Larangan persekongkolan merupakan salah satu kegiatan yang dilarang dalam hukum persaingan usaha, yakni sebagaimana tercantum dalam UU Nomor 5 Tahun 1999 sebagai berikut :13

1. Pasal 22 : "Pelaku usaha dilarang bersekongkol dengan pihak lain untuk mengatur dan atau menentukan pemenang tender sehingga dapat mengakibatkan terjadinya persaingan usaha tidak sehat"

11 Rachmadi Usman. 2004. Hukum Persaingan Usaha di Indonesia. Jakarta: Gramedia Pustaka Utama, hlm 79.

12 Pasal 22 Undang-Undang Nomor 5 Tahun 1999 Tentang Larangan Persekongkolan dalam Tender 
2. Pasal 23 : "Pelaku usaha dilarang bersekongkol dengan pihak lain untuk mendapatkan informasi kegiatan usaha pesaingnya yang diklasifikasikan sebagai rahasia perusahaan sehingga dapat mengakibatkan terjadinya persaingan usaha tidak sehat"

3. Pasal 24 : Pelaku usaha dilarang bersekongkol dengan pihak lain untuk menghambat produksi dan atau pemasaran barang dan atau jasa pelaku usaha pesaingnya dengan maksud agar barang dan atau jasa yang ditawarkan atau dipasok di pasar bersangkutan menjadi berkurang baik dari jumlah, kualitas maupun ketetapan waktu yang disyaratkan.

Jasa persekongkolan ini dapat melibatkan dua atau tiga pihak yang terkait dalam proses tender.

Pengertian tender dalam prakteknya memiliki kesamaan pengertian dengan lelang sebagaimana diatur dalam Perpres Nomor 54 Tahun 2010, contohnya dalam metode pemilihan penyedia barang dan jasa, dapat dilakukan dengan cara pelelangan umum dan pelelangan terbatas. Ketentuan pasal di atas merupakan dasar adanya larangan tindakan persekongkolan tender. Sedangkan pengertian tender terdapat dalam penjelasan UndangUndang Nomor 5 Tahun 1999. Dengan demikian ruang lingkup tender adalah: ${ }^{14}$

${ }^{13}$ Muskibah, Op Cit, hlm 61-63.

14 L. Budi Kagramanto, Op Cit, hlm 62-63.
1. Tawaran untuk mengajukan harga terendah untuk memborong suatu pekerjaan, seperti membangun atau merenovasi gedung pemerintah.

2. Tawaran untuk mengajukan harga terendah untuk pengadaan barang, seperti memasok kebutuhan alat-alat tulis dan perlengkapan kantor di instansi pemerintah.

3. Tawaran untuk mengajukan harga terendah untuk menyediakan jasa seperti: jasa cleaning service atau jasa konsultan keuangan lembaga pemerintah.

4. Tawaran untuk mengajukan harga tertinggi seperti penawaran atau penjualan lelang barang-barang inventaris atau barang sitaan pemerintah yang perolehannya melanggar hukum.

Dengan demikian istilah tender merupakan suatu bentuk kerjasama antara dua atau lebih pelaku usaha dalam rangka memenangkan peserta tender tertentu. Kerjasama dilakukan oleh satu atau lebih peserta yang menyetujui seorang peserta tertentu dengan harga lebih rendah, dimana peserta lainnya melakukan penawaran dengan harga yang lebih rendah, dimana peserta tertentu melakukan penawaran dengan harga di atas harga perusahaan yang akan dimenangkan. Kesepakatan tersebut bertentangan dengan proses tender atau pelelangan yang semestinya terjadi, karena penawaran pada umumnya dirancang untuk menciptakan keadilan dan menjamin 
yang dihasilkan adalah harga yang murah dan efisien. Oleh karena itu, tindakan persekongkolan dalam tender dianggap menghalangi terciptanya persaingan yang sehat di kalangan pelaku usaha yang beritikad baik untuk melakukan usaha di bidang yang bersangkutan.

Apabila melihat secara saksama tujuan adanya UU Nomor 5 Tahun 1999, dapat dikatakan bahwa pada dasarnya tujuan penegakan hukum persaingan usaha adalah untuk meningkatkan kesejahteraan masyrakat, mencegah prakter monopoli atau persaingan yang tidak sehat. Lebih dari itu, untuk mengawasi jalannya penegakan terhadap tindakan persekongkolan tender atau pelelangan, kemudian diimplementasikan Keputusan Presiden Republik Indonesia Nomor 75 Tahun 1999 tentang Komisi Pengawas Persaingan Usaha Republik Indonesia institusi yang diberi kewenangan oleh negara untuk menangani perkaraperkara pelanggaran hukum persaingan usaha yaitu Komisi Pengawas Persaingan Usaha (selanjutnya disebut KPPU). Pembentukan ini didasarkan pada Pasal 34 UU Nomor 5 Tahun 1999 yang menginstrusikan pembentukan susunan organisasi, tugas, dan fungsi komisi ditetapkan oleh Keputusan Presiden.

KPPU merupakan suatu organ khusus yang mempunyai tugas ganda, yaitu selain menciptakan ketertiban dalam persaingan usaha juga berperan untuk menciptakan dan memelihara iklim persaingan usaha yang kondusif. Meskipun KPPU mempunyai fungsi penegakan hukum khususnya hukum persaingan usaha, namun KPPU bukanlah lembaga peradilan khusus persaingan usaha. ${ }^{15}$

Dalam penegakan hukum perkara pelanggaran terhadap persaingan usaha termasuk di dalamnya pelanggaran terhadap larangan persekongkolan tender, KPPU wajib memberikan putusan selambat-lambatnya 150 (seratus lima puluh) hari sejak perkara tersebut diajukan. Keputusan KPPU ini mempunyai kekuatan hukum yang tetap, jika tidak ada keberatan yang diajukan oleh pelaku usaha ke Pengadilan Negeri. Pengadilan Negeri harus memberi putusan dalam waktu 30 (tiga puluh) hari sejak dimulainya pemeriksaan. Atas keputusan Pengadilan Negeri ini, masih dapat diajukan kasasi ke Mahkamah Agung.

Adapun sanksi yang dapat dijatuhkan kepada pelaku usaha yang melakukan persaingan usaha tidak sehat berdasarkan UU Nomor 5 Tahun 1999 adalah sanksi administratif dan sanksi pidana. Sanksi administratif: ${ }^{16}$

1. Komisi berwenang menjatuhkan sanksi berupa tindakan administratif terhadap pelaku usaha yang melanggar ketentuan undang-undang ini.

\footnotetext{
15 Yuliana Juwita. 2012. Larangan Persekongkolan Tender Berdasarkan Hukum Persaingan Usaha, Suatu Perbandingan Pengaturan di Indonesia dan Jepang, Tesis, Program Pasca Sarjana Fakultas Hukum Universitas Indonesia, hlm. 46.

16 Pasal 47 Undang-Undang Nomor 5 Tahun 1999 Tentang Larangan Persekongkolan dalam Tender
} 
2. Tindakan administratif sebagaimana dimaksud dalam ayat (1) dapat berupa:

a. Penetapan pembatalan perjanjian sebagaimana dimaksud dalam Pasal 4 sampai dengan Pasal 13, Pasal 15 dan Pasal 16, dan atau

b. Perintah kepada pelaku usaha untuk menghentikan integrasi vertikal sebagaimana dimaksud dalam Pasal 14 dan atau,

c. Perintah kepada pelaku usaha untuk menghentikan kegiatan yang terbukti menimbulkan praktik monopoli dan atau menyebabkan persaingan usaha tidak sehat dan atau merugikan masyarakat, dan atau perintah kepada pelaku usaha untuk menghentikan penyalahgunaan posisi dominan dan atau,

d. Penetapan pembatalan atas penggabungan atau peleburan badan usaha dan pengambilalihan saham sebagaimana dimaksud Pasal 28 dan,

e. Pengenaan pembayaran ganti rugi, dan atau

f. Pengenaan denda serendahrendahnya $\mathrm{Rp}$. $\quad 1.000 .000 .000$ (satu miliar rupiah) dan setinggitingginya Rp. 25.000.000.000 (dua puluh lima miliar rupiah). “

Selain sanksi administartif kemudian terdapat sanksi pidana, yakni: ${ }^{17}$

\footnotetext{
17 Pasal 48 Undang - Undang Nomor 5 Tahun 1999 Tentang Larangan Persekongkolan dalam Tender
}

1. Pelanggaran terhadap ketentuan Pasal 4, Pasal 9 sampai dengan Pasal 14, Pasal 16 sampai dengan Pasal 19, Pasal 25 dan Pasal 28 diancam pidana denda serendah-rendahnya Rp. 25.000.000.000 (dua puluh lima miliar rupiah) dan setinggi-tingginya $\mathrm{Rp}$. 100.000.000.000 (seratus miliar rupiah) atau pidana kurungan pengganti denda selama-lamanya 6 (enam) bulan.

2. Pelanggaran terhadap ketentuan Pasal 5, sampai dengan Pasal 8, Pasal 15, Pasal 20 sampai dengan Pasal 24 dan Pasal 26, diancam pidana denda serendah-rendahnya Rp. 5.000.000.000 ( lima miliar rupiah) dan setinggi-tingginya Rp. 25.000.000.000 (dua puluh lima miliar rupiah) atau pidana kurungan pengganti denda selama-lamanya 5 (lima) bulan.

3. Pelanggaran terhadap ketentuan Pasal 41, diancam pidana denda serendah rendahnya Rp. 1.000.000.000 ( satu miliar rupiah) dan setinggi-tingginya Rp. 5.000.000.000 ( lima miliar rupiah) atau pidana kurungan pengganti denda selama-lamanya 3 (tiga bulan)." Selanjutnya sanksi pidana yang menyatakan dengan menunjuk ketentuan Pasal 10 KUHP, terhadap pidana sebagaimana diatur dalam Pasal 48 dapat dijatuhkan pidana tambahan berupa : ${ }^{18}$

1. Pencabutan izin usaha atau

\footnotetext{
18 Pasal 49 Undang - Undang Nomor 5 Tahun 1999 Tentang Larangan Persekongkolan dalam Tender
} 
2. Larangan kepada pelaku usaha yang telah terbukti melakukan pelanggaran terhadap Undang - Undang ini untuk menduduki jabatan Direksi atau Komisaris sekurang-kurangnya 2 (dua) tahun dan selama-lamanya 5 (lima) tahun atau

3. Penghentian kegiatan atau tindakan tertentu yang menyebabkan timbulnya kerugian pada pihak lain.

Apabila dikaji ketentuan sanksi yang tersebut di atas, maka sanksi administratif yang dapat diterapkan kepada pelaku usaha yang melakukan persekongkolan dalam tender adalah berupa perintah kepada pelaku usaha untuk menghentikan kegiatan yang terbukti menimbulkan praktik monopoli dan persaingan usaha tidak sehat (Pasal 47 ayat (2) huruf c), pengenaan pembayaran ganti rugi (Pasal 47 ayat (2) huruf f), dan Pengenaan denda (Pasal 47 ayat 2 huruf g).

Selanjutnya untuk sanksi pidana, dapat diterapkan ketentuan Pasal 48 ayat (2), yaitu denda serendah-rendahnya Rp. 5.000.000.000 (lima milyar rupiah) dan setinggi-tingginya Rp.25.000.000.000 (dua puluh lima milyar rupiah) atau pidana kurungan pengganti selama 5 (lima) bulan. Sedangkan untuk pidana tambahan dapat dikenakan semua atau salah satu dari ketentuan Pasal 49.

\section{B. Dampak yang Akan Dialami Konsumen Apabila Terjadi Tindakan Persekongkolan Dalam Tender Dikaitan Dengan Perlindungan Konsumen.}

Persaingan usaha tidak sehat dapat mengakibatkan konsumen dirugikan, oleh karena itu Negara wajib melindungi konsumen dengan membuat perundangundangan yang bertujuan mengatur persaingan antar pelaku usaha dan perlindungan kepada konsumen. Di banyak negara Institusi yang mengawasi persaingan usaha tidak sehat dan perlindungan konsumen dijadikan satu, di Indonesia kedua hal tersebut di atas diatur dalam dua Undang - Undang yang berbeda.

Istilah perlindungan konsumen berkaitan dengan perlindungan hukum. Oleh karenanya perlindungan konsumen mengandung aspek hukum. Adapun materi yang mendapatkan perlindungan itu bukan sekedar fisik, melainkan terlebih kepada hak yang bersifat abstrak. Dengan kata lain perlindungan konsumen sesungguhnya identik dengan perlindungan yang diberikan hukum tentang hak-hak konsumen. ${ }^{19}$

Untuk persaingan usaha tidak sehat diatur dalam UU Nomor 5 Tahun 1999. Institusi yang mengawasi adalah Komisi Pengawas Persaingan Usaha (KPPU). Sedangkan untuk Perlindungan Konsumen

19 Celina Tri Siwi Kristiyanti. 2008. Hukum Perlindungan Konsumen. Jakarta: Sinar Grafika. hlm 30. 
di atur melalui Undang - Undang Nomor 8 Tahun 1999 tentang Perlindungan Konsumen (selanjutnya disebut UUPK). Lembaga yang mengawasi adalah Badan Perlindungan Konsumen Nasional (BPKN).

Berdasarkan pasal 1 angka 1 UU Perlindungan Konsumen Nomor 8 Tahun 1999 disebutkan perlindungan konsumen adalah segala upaya yang menjamin adanya kepastian hukum untuk memberikan perlindungan kepada konsumen. Konsumen berdasarkan UU di atas diartikan adalah setiap orang pemakai barang dan atau jasa yang tersedia dalam masyarakat, baik bagi kepentingan sendiri, keluarga, orang lain, maupun makhluk hidup lain, dan tidak untuk diperdagangkan. ${ }^{20}$

Pasal 1 ayat (1) dan (2) menjelaskan pengertian Konsumen adalah setiap orang pemakai barang dan atau jasa yang tersedia dalam masyarakat, baik bagi kepentingan sendiri, keluarga, orang lain maupun makhluk hidup lain dan tidak untuk diperdagangkan. Sedangkan pengertian pelaku usaha adalah setiap orang perseorangan atau badan hukum, baik yang berbentuk badan maupun bukan badan hukum yang didirikan dan berkedudukan atau melakukan kegiatan dalam wilayah hukum Republik Indonesia, baik sendiri, maupun bersama-sama melalui perjanian menyelenggarakan kegiatan usaha dalam bidang ekonomi.

\footnotetext{
20 Ahmadi Miru dan Sutarman Yoda. 2011. Hukum Perlindungan Konsumen. Jakarta: Raja Grafindo Persada, hlm. 1.
}

Berkaitan dengan pengertian diatas, maka dalam tindakan persekongkolan dalam tender, konsumen yang dimaksud adalah pemberi tender, sedangkan pelaku usaha yang dimaksud adalah penerima tender.

Secara umum dikenal ada 4 (empat) hak dasar konsumen, yaitu:21

1. Hak untuk mendapatkan keamanan (the right to safety),

2. Hak untuk mendapatkan informasi (the right to be informed),

3. Hak untuk memilih (the right to choose,)

4. Hak untuk didengar (the right to be heard).

Hak-hak konsumen sebagaimana termuat dalam UUPK bersifat terbuka, artinya selain ada hak-hak konsumen yang diatur dalam UUPK, dimungkinkan diakuinya hak-hak konsumen lainnya yang tidak diatur dalam UUPK, tetapi diatur dalam peraturan perundang-undangan lain disektor tertentu. Hal ini merupakan konsekuensi logis dari status UUPK sebagai ketentuan payung (umbrella rule). ${ }^{22}$

Menurut Pasal 5 UUPK, kewajiban konsumen, diantara lain sebagai berikut:

1. Membaca atau mengikuti petunjuk informasi dan prosedur pemakaian atau pemanfaatan barang dan atau jasa, demi keamanan dan keselamatan,

21 Shidarta. 2000. Hukum Perlindungan Konsumen. Jakarta: Grasindo, hlm 16.

22 Wahyu Sasongko. 2007. Ketentuan-Ketentuan Pokok Hukum Perlindungan Konsumen. Bandar Lampung: Penerbit Universitas Lampung, hIm 62. 
2. Beritikad baik dalam melakukan transaksi pembelian barang dan atau jasa,

3. Membayar sesuai dengan nilai tukar yang disepakati,

4. Mengikuti upaya penyelesaian hukum sengketa perlindungan konsumen secara patut.

Dalam pasal pasal 7 angka (1) sampai dengan (3) UUPK menjelaskan bahwa kewajiban dari pelaku usaha adalah;

1. Beritikad baik dalam melakukan kegiatan usahanya,

2. Memberikan informasi yang benar, jelas, jujur mengenai kondisi dan jaminan barang dan jasa serta memberi penjelasan penggunaan, perbaikan dan pemeliharaan,

3. Memperlakukan atau melayani konsumen secara benar dan jujur serta tidak diskriminatif.

Persekongkolan tender merupakan suatu kegiatan yang dilakukan para pelaku usaha dengan cara melakukan kesepakatan-kesepakatan yang bertujuan memenangkan tender. Kegiatan ini akan berimplikasi pada pelaku usaha lain yang tidak ikut dalam kesepakatan tersebut, dan tidak jarang mengakibatkan kerugian bagi pihak pengguna penyedia jasa atau barang karena adanya ketidakwajaran harga. ${ }^{23}$ Dalam kasus persekongkolan dalam tender konsumen atau pemberi kerja juga

23 Gianjar Bowo Saputra. Hernawan Hadi. 2018. "Penegakan, Hukum Persekongkolan Tender Menurut Undang-Undang 5 Tahun 1999 Tentang Larangan Praktik Monopoli dan Persaingan Usaha Tidak Sehat”, Privat Law, VI (2), hlm. 215. mengalami dampak kerugian. Dilihat dari sisi konsumen atau pemberi kerja, tindakan persekongkolan dalam tender berdampak antara lain;

1. Konsumen atau pemberi kerja membayar harga yang lebih mahal dari pada yang sesungguhnya.

2. Barang atau jasa yang diperoleh (baik dari sisi mutu, jumlah, waktu, maupun nilai) seringkali lebih rendah dari yang akan diperoleh apabila tender dilakukan secara jujur.

3. Terjadi hambatan pasar bagi peserta potensial yang tidak memperoleh kesempatan untuk mengikuti dan memenangkan tender.

4. Nilai proyek (untuk tender pengadaan jasa) menjadi lebih tinggi akibat mark up yang dilakukan oleh pihak-pihak yang bersekongkol. Apabila hal tersebut dilakukan dalam proyek Pemerintah yang pembiayaannya.

Kepentingan konsumen merupakan salah satu aspek dari tujuan persaingan usaha (kepentingan umum) dalam hal ini dampak terhadap konsumen ditinjau dikaitkan dengan perlindungan konsumen adalah jelas berupa kerugian yakni:

1. Kerugian pada hak-hak konsumen akibat mutu barang di bawah standar bisa dirasakan akibatnya secara langsung oleh konsumen, pelanggaran hak-hak konsumen karena struktur market yang distortif atau dikarenkan kegiatan pengadaan jasa dimana nilai proyek tidak sesuai, sering kali konsumen tidak sadar bahwa hak- 
haknya sebagai konsumen dilanggar karena harus membayar harga yang tidak wajar dari yang seharusnya konsumen bayar.

2. Kerugian material berupa uang, barang ataupun tenaga ahli,

3. Kerugian akibat mengkonsumsi barang dan/atau jasa yang dihasilkan atau diperdagangkan.

\section{Penutup}

Penegakan hukum terhadap pelanggaran larangan persekongkolan tender sebagaimana yang diatur dalam Pasal 22 sanksi yang dapat diterapkan terhadap pelanggaran Pasal 22 tersebut adalah sebagaimana yang tercantum dalam Pasal 47 ayat 2 huruf $c$, huruf $f$ dan huruf $g$, serta untuk pidana diterapkan ketentuan Pasal 48 ayat (2), serta Pasal 49 untuk pidana tambahan. Bahwa persekongkolan dalam tender berdampak kepada kerugian yang sangat bersar terhadap hak-hak konsumen itu sendiri. Dalam hal ini konsumen akan mengalami kerugian materiil seperti uang dan materiil, serta kerugian immateriil seperti waktu serta tenaga.

Dalam hal ini penulis berpendapat pihak KPPU selaku instusi yang mengatasi persaingan usaha dalam memberikan sanksi harus sesuai dengan UndangUndang Larangan Praktek Monopoli dan Persaingan Usaha Tidak Sehat. Selain itu dalam mengawasi kegiatan tender harus lebih tegas, sehingga mengurangi terjadi persaingan usaha tidak sehat. Sebaiknya setiap badan atau lembaga yang mengadakan tender harus lebih professional dan mementingkan kualitas dan kuantitas.

\section{Bibliografi}

\section{Buku}

Ahmadi Miru dan Sutarman Yoda. 2011.

Hukum Perlindungan Konsumen. Jakarta: Raja Grafindo Persada.

Celina Tri Siwi Kristiyanti. 2008. Hukum Perlindungan Konsumen. Jakarta: Sinar Grafika.

Dellyana Shant. 1988. Konsep Penegakan

Hukum. Yogyakarta: Liberty.

Faisal Basri. 2002. Perekonomian Indonesia, Tantangan dan Harapan Bagi Kebangkitan Indonesia. Jakarta: Erlangga.

Jimly Asshiddiqie. 1998. Agenda Pembangunan Hukum Nasional Di Abad Globalisasi. Jakarta: Balai Pustaka.

L. Budi Kagramanto. 2008. Larangan

Persekongkoan Tender (Perspektif

Hukum Persaingan Usaha).

Surabaya: Srikandi.

Rachmadi Usman. 2004. Hukum Persaingan Usaha di Indonesia. Jakarta: Gramedia Pustaka Utama. 2013. Hukum Persaingan Usaha Di Indonesia. Jakarta: Sinar Grafika.

Shidarta. 2000. Hukum Perlindungan Konsumen. Jakarta: Grasindo.

Sudikno Metrokusumo. 2003. Mengenal Hukum (suatu pengantar). Yogyakarta: Liberty. 
Wahyu Sasongko. 2007. KetentuanKetentuan Pokok Hukum Perlindungan Konsumen. Bandar Lampung: Penerbit Universitas Lampung.

\section{Jurnal}

Gianjar Bowo Saputra. Hernawan Hadi. 2018. "Penegakan, Hukum Persekongkolan Tender Menurut Undang-Undang 5 Tahun 1999 Tentang Larangan Praktik Monopoli dan Persaingan Usaha Tidak Sehat". Privat Law, VI (2).

Muskibah.

2013.

"Larangan

Persekongkolan Dalam Tender

Perspektif Undang-Undang Nomor

5 Tahun 1999 Tentang Larangan

Praktek Monopoli Dan Persaingan

Usaha Tidak Sehat". Jurnal Hukum, $6(7)$.

Octaviana Pramustika Puteri, Teddy Anggoro. 2013. "Dugaan Praktel Persaingan Usaha Tidak Sehat Dalam Proyek Pembangunan Pegangasaan Timur Cikini Ditinjau Dari Undang-Undang Nomor 5 Tahun 1999 Tentang Larangan Praktek Monopoli dan Persaingan Usaha Tidak Sehat" Jurnal Hukum.

Rai Mantili, dkk. 2016. "Problematika Penegakan Hukum Persaingan Usaha di Indonesia dalam Rangka Menciptakan Kepastian Hukum". Jurnal Hukum, 3 (1).

Riski Dysas Prabawani, Munawar Kholil. 2017. "Analisis Yuridis Penegakan
Hukum Persekongkolan Tender Menurut Undang-Undang Nomor 5 Tahun 1999 Tentang Larangan Praktik Monopoli Dan Persaingan Usaha Tidak Sehat". Privat Law, V (2).

Yakub Adi Krisanto. 2008. "Terobosan Hukum Keputusan KPPU dalam Mengembangkan Penafsiran Hukum Persekongkolan Tender", Jurnal Hukum Bisnis, 27 (3).

\section{Perundang-Undangan}

Undang-Undang Nomor 5 Tahun 1999 Tentang Larangan Praktek Monopoli dan Persaingan Usaha Tidak Sehat (Lembaran Negara Republik Indonesia Tahun 1999 Nomor 33).

Undang-Undang Nomor 8 Tahun 1999 Tentang Perlindungan Konsummen (Lembaran Negara Republik Indonesia Tahun 1999 Nomor 42)

Tesis

Yuliana Juwita. 2012. Larangan Persekongkolan Tender Berdasarkan Hukum Persaingan Usaha, Suatu Perbandingan Pengaturan di Indonesia dan Jepang. Tesis, Program Pasca Sarjana Fakultas Hukum Universitas Indonesia, Depok.

\section{Internet}

www.jimly.com/makalah/namafle/56/Peneg akan_Hukum.pdf.

www./juzrifara.blogspot.com/2017/01/teorisistem-hukum-friedman.html 